\title{
Occipital locked headache
}

\author{
A Whitehouse, A Momoh-Ojewuyi, R Abusamara*, S Al-Ani, R Alkilani, MAS Ahmed \\ From The European Headache and Migraine Trust International Congress \\ London, UK. 20-23 September 2012
}

\section{Methods}

Clinical data for 1029 patients (588 females; 627 Caucasians; mean age $=11.4$ years) with headaches were prospectively examined in this hospital based study. Headache diagnosis was made on the basis of ICHD - II, 2004. 1. Headache diagnosis included migraine $(n=598)$; tension type headaches $(\mathrm{n}=158)$; other headache types $(n=91)$ and remained unclassified $(n=182)$ patients. We have adopted previous descriptions of terms for anatomical sites for headache location. 2. Occipital locked headache $(\mathrm{OLH})$ is defined as headache that is for all time fixed to the occipital region and never changed side.

\section{Results}

48/1029 (4.7\%) of patients experienced recurrent OLH during a mean headache course of 2.3 years. It was more for OLH to localise bilaterally $(87.5 \%)$ as only four $(8 \%)$ and two $(4 \%)$ patients had right and left OLH respectively. Headache diagnosis was migraine $(n=29)$; tension type headaches $(n=5)$; and other headache types $(n=5)$. Headache remained unclassified in 10/48 patients. Brain imaging was either normal $(n=46)$ or showed no significant abnormalities $(\mathrm{n}=2)$.

\section{Discussion}

In this study, sinister aetiologies of OLH were excluded among our patients. Primary headache was found to be the most common headache category among patients with OLH. Frequency of OLH was $5 \%$ and $4.4 \%$ patients with migraine and those with non-migraine headaches respectively.

\section{Conclusion}

Primary headaches such as migraine and TTH are common causes of OLH, although OLH was infrequently found among patients with migraine and those with other primary headache types.

Barking Havering \& Redbridge NHS Trust, UK
Published: 21 February 2013

\section{References}

1. International Headache Society, ICHD-II: . Cephalalgia 2004, 24(Suppl 1).

2. Chakravarty A, et al.. J Headache Pain 2008, 9:375-379.

doi:10.1186/1129-2377-14-S1-P181

Cite this article as: Whitehouse et al:: Occipital locked headache. The

Journal of Headache and Pain 2013 14(Suppl 1):P181.

\section{SpringerOpen $^{\circ}$}

(C) 2013 Whitehouse et al; licensee Springer. This is an Open Access article distributed under the terms of the Creative Commons Attribution License (http://creativecommons.org/licenses/by/2.0), which permits unrestricted use, distribution, and reproduction in any medium, provided the original work is properly cited.
Submit your manuscript to a SpringerOpen ${ }^{\circ}$ journal and benefit from:

- Convenient online submission

- Rigorous peer review

- Immediate publication on acceptance

- Open access: articles freely available online

- High visibility within the field

- Retaining the copyright to your article

Submit your next manuscript at $>$ springeropen.com 